\title{
Estimation of Generated and Retained Gas Volume of the Besa River Formation in Liard Basin through 3-Dimensional Static Geochemical Modeling
}

\author{
Kwang Hyun Kim, ${ }^{1}$ Sung Kyung Hong, ${ }^{1}$ Jiyoung Choi, ${ }^{1}$ Kyungbook Lee $\mathbb{D}^{1,2}$ Andy Mort, ${ }^{3}$ \\ and Hyun Suk Lee $\mathbb{1}^{1}$ \\ ${ }^{1}$ Petroleum and Marine Research Division, Korea Institute of Geoscience and Mineral Resources, Daejeon 34132, Republic of Korea \\ ${ }^{2}$ Department of Geoenvironmental Sciences, Kongju National University, Gongju, Chungnam 32588, Republic of Korea \\ ${ }^{3}$ Geological Survey of Canada, Natural Resources Canada, Calgary, Canada T2L 2A7 \\ Correspondence should be addressed to Hyun Suk Lee; hyun0922@kigam.re.kr
}

Received 30 June 2020; Revised 5 November 2020; Accepted 19 November 2020; Published 2 December 2020

Academic Editor: Andrew H. Manning

Copyright (c) 2020 Kwang Hyun Kim et al. This is an open access article distributed under the Creative Commons Attribution License, which permits unrestricted use, distribution, and reproduction in any medium, provided the original work is properly cited.

\begin{abstract}
The Besa River Formation mainly comprises argillaceous sediments, and the upper shale bed of the Formation has been considered as a prospective shale gas reservoir. The maturity and quantity of organic matter found in source rock are considered as factors for evaluating resource value. Original hydrogen index (HIo) and total organic carbon (TOCo) are considered as properties to estimate generated gas volume in shale gas reservoirs. Generally, TOCo and HIo are determined via geochemical analysis of organic matter and calculated from well-log data like density, sonic data, and resistivity. In this study, these properties were measured or calculated by using geological analysis data and bulk-density log, and then the prospective area from the geochemical perspective in Liard Basin is defined by realizing a 3-dimensional static geochemical model. To validate the static model, the gas-in-place (GIP) ( $496 \mathrm{Bcf} /$ section) of the production well in this study area was compared with GIP ( $262 \mathrm{Bcf} / \mathrm{section})$ in the static model. Expulsion efficiency was considered as 0.6 . The result implies that this model has a method of informative assessment with regard to undeveloped shale gas resources. The static model provides spatial information for generated and retained gas volume in the Besa River Formation, Liard Basin.
\end{abstract}

\section{Introduction}

Shale resources in several unconventional fields such as Horn River, Montney, Cordova Embayment, and Liard in British Columbia have been developed or produced. Among these, the Liard Basin has been evaluated as a gas-in-place (GIP) resource of 848 trillion cubic feet (Tcf) and initial raw gas reserves of 0.1 Tcf in the Exshaw and Patry beds $[1,2]$. The GIP of the Liard is almost double that of the Horn River Basin, and its ratio of reserves per resource shows the least value among the basins [1]. This indicates that the Liard Basin has a higher potential than the other fields.

The shale gas resource is source rock and reservoir rock; for this reason, the evaluation method for the source rock can be applied for the unconventional resource [3-6].
Many researches have been evaluating shale gas reservoirs by using geochemical analysis and petroleum system modeling. The system modeling gives information about evolution of petroleum system and thermal maturity of regional source rock $[7,8]$.

However, the model needs various and abundant data ranging from geochemical data to depositional history $[7,8]$. Moreover, the generative potential of shale gas resources can be estimated by initial geochemical properties such as the original hydrogen index (HIo) and original total organic carbon (TOCo) $[9,10]$. For these reasons, the 3dimensional static geochemical model will be suggested by a method to define promising spots in the basin, such as Liard Basin, where there is not enough data for petroleum system modeling. In this study, geochemical analysis and 


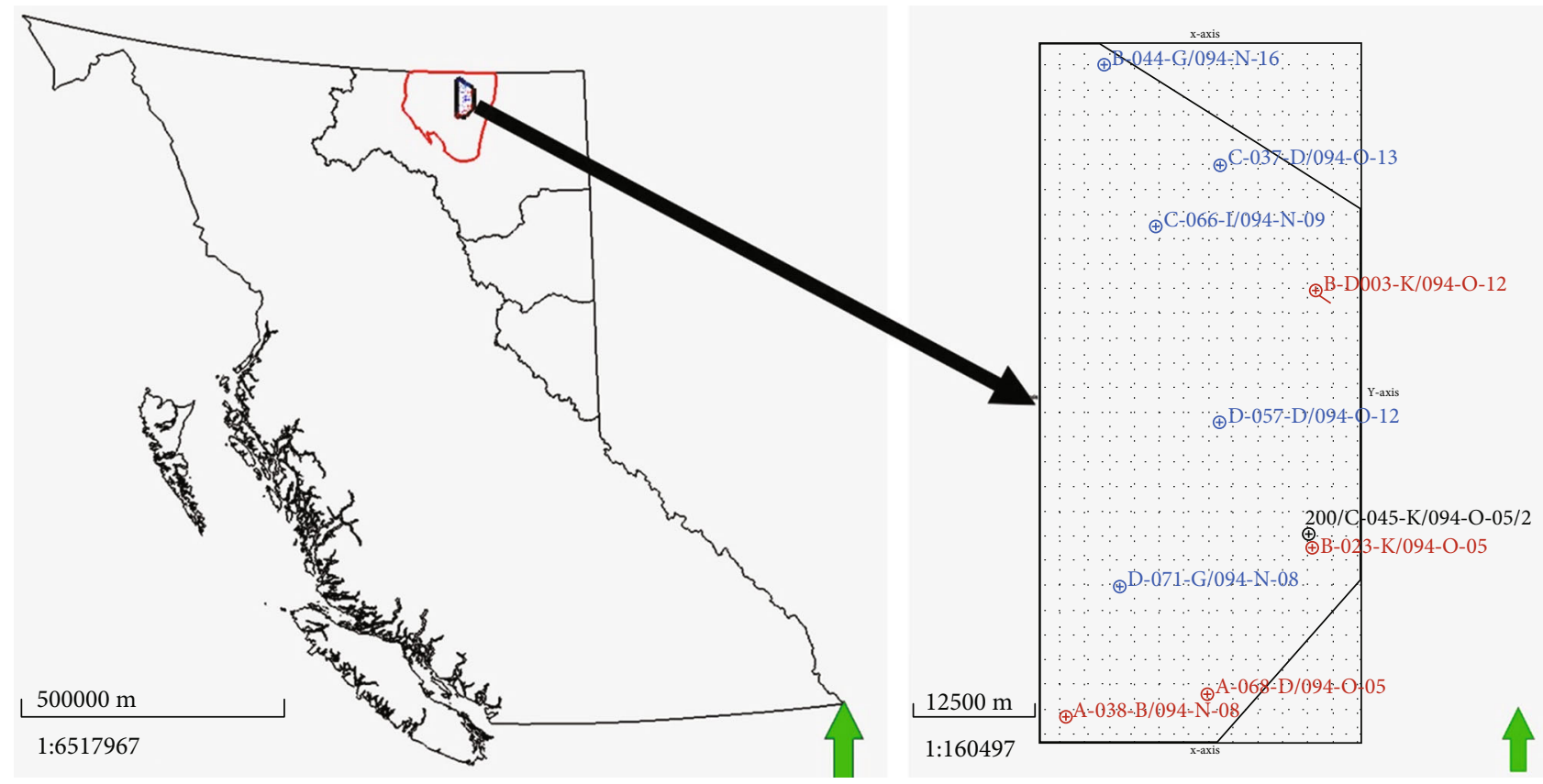

FIGURE 1: Location of Liard Basin (red line) in British Columbia (left) and location of boreholes in the study area (right). Red color-indicated boreholes have geochemical properties determined by Rock-Eval pyrolysis and well-log data, whereas blue color-indicated boreholes only have well-log data. Black color indicates production well.

TABLE 1: Range of measured parameters by Rock-Eval analysis in the four boreholes.

\begin{tabular}{lccccccc}
\hline Well name & $\begin{array}{c}\mathrm{S} 1 \\
(\mathrm{mgHC} / \mathrm{gRock})\end{array}$ & $\begin{array}{c}\mathrm{S} 2 \\
(\mathrm{mgHC} / \mathrm{gRock})\end{array}$ & $\begin{array}{c}\mathrm{S} 3 \\
\left(\mathrm{mgCO}_{2} / \mathrm{gRock}\right)\end{array}$ & $\begin{array}{c}\text { Tmax } \\
\left({ }^{\circ} \mathrm{C}\right)\end{array}$ & $\begin{array}{c}\mathrm{HI} \\
(\mathrm{mgHC} / \mathrm{gTOC})\end{array}$ & $\begin{array}{c}\text { OI } \\
\left(\mathrm{mgCO}_{2} / \mathrm{gTOC}\right)\end{array}$ & $\begin{array}{c}\text { TOCpd } \\
(\mathrm{wt} \%)\end{array}$ \\
\hline A-038-B/094-N-08 & $0.1-4.24$ & $0.18-2.53$ & $0.04-0.79$ & $303-363$ & $3-36$ & $1-18$ & $1.63-13.22$ \\
A-068-D/094-O-05 & $0.14-5.52$ & $0.08-2.73$ & $0.02-0.6$ & $289-356$ & $3-48$ & $1-43$ \\
B-023-K/094-O-05 & $0.08-4.56$ & $0.12-1.99$ & $0-0.4$ & $292-610$ & $4-39$ & $0.89-16.75$ \\
B-D003-K/094-O-12 & $0.1-7.94$ & $0.07-2.71$ & $0.02-0.4$ & $293-354$ & $3-41$ & $1.85-6.26$ \\
\hline
\end{tabular}

Abbreviation: S1: the amount of free hydrocarbons; S2: the amount of generated hydrocarbons by thermal cracking; $\mathrm{S}$ : the amount of generated $\mathrm{CO}_{2}$ by thermal cracking of kerogen; HI: hydrogen index; OI: oxygen index; TOCpd: present-day total organic carbon.

well-log data are used to estimate the generative potential based on the original geochemical data in the Besa River Formation, Liard Basin.

\section{Study Area and General Geology}

The Liard Basin spans across the British Columbia, Yukon, and N.W. Territories [11]. The study area lies in British Columbia; specifically, the area is Series number 94 and Area codes N to O on the NTS (National Topographic System) coordinate system (Figure 1). It stretches $32 \mathrm{~km}$ in the east to west direction and $70 \mathrm{~km}$ in the north to south direction and has an area of $1,947 \mathrm{~km}^{2}$.

The Besa River Formation was deposited during the middle Devonian to early Carboniferous [11]. The Formation comprises predominantly argillaceous rocks, which are massive to bedded in texture, grey to black in color, and calcareous to noncalcareous [11-14]; minor sandstone and siltstone are interbedded locally $[1,11,13,14]$. The depositional environment is interpreted as the marine slope into the deep marine environment [11] under anoxic condition [12, 15, 16].

\section{Data and Methods}

Experimental analysis data by the Rock-Eval pyrolysis and XRF (X-ray fluorescence spectrometer) of four boreholes (Figure 1) were based on data of Hong et al. (A-038-B/094N-08) [17], Kim et al. (A-068-D/094-O-05) [18], and Choi et al. (B-023-D/094-O-05 and B-D003-K/094-O-12) [19] (Table 1).

The structural frame of the model considered the geological interpretation of the reservoir in order to realize the $3 \mathrm{D}$ distribution for geochemical properties (Figure 2). Hence, the shale bed was classified in terms of hydrocarbon generation potential. The correlation of prospective shale beds in the formation nine boreholes was conducted using gammaray (GR) log. The distance between the boreholes was considered as the boundary of the study area.

In this study, the original total organic carbon (TOCo) and original hydrogen index (HIo) are determined to estimate the hydrocarbon $(\mathrm{HC})$ generative potential. These were calculated based on mineralogical and geochemical analysis data $[9,10,15]$. The TOCo data cannot be directly obtained 


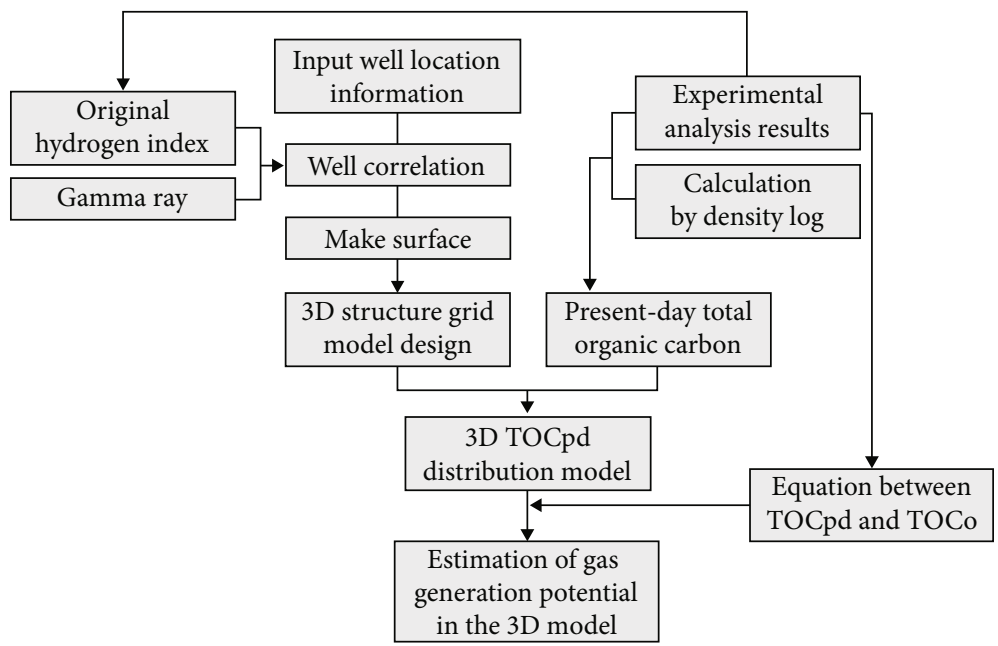

Figure 2: 3D static geochemical modeling workflow.

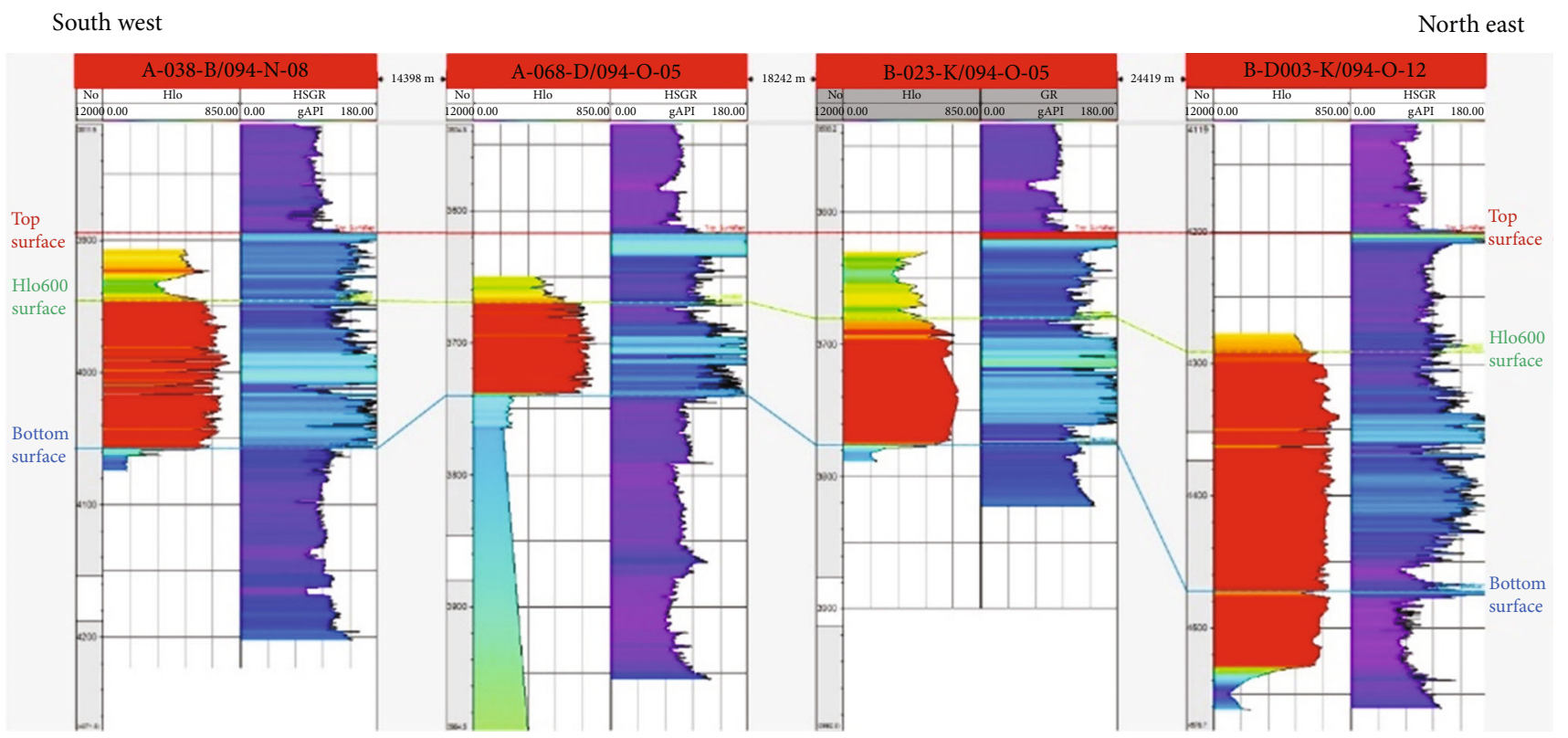

FIGURE 3: Stratigraphic correlation figures using original hydrogen index and gamma-ray log.

from the rock sample directly; hence, the present-day total organic carbon (TOCpd) was determined using bulk density $\log [20,21]$ and Rock-Eval pyrolysis data. Geochemical property models were realized in the structure grid model.

This study undertook 3D shale gas reservoir characterization considering the geochemical properties in the prospective shale beds of the Besa River Formation, Liard Basin. From the model, generated gas volume was estimated, and the volume was compared with the GIP of a production well in this study area and the well location in the model.

3.1. Structure Modeling. To realize the spatial distribution of organic matter, horizontal grid size was considered by distance between the boreholes $(500 \times 500 \mathrm{~m})$; the vertical interval of the grid was considered as $10 \mathrm{~m}$. Hydrogen index (HI) is a generally used indicator to predict thermal maturity for source, but it is difficult to predict thermal maturity exactly in mature and overmature source rocks using estimated present-day HI. For this reason, the original hydrogen index (HIo) is considered to more accurately estimate generated gas volume by TOCo; it was calculated by Equation (1) $[9,10,15]$ with data [17-19].

HIo $=600 \times$ Fraction of Type II Kerogen +200 .

The prospective shale beds were classified as upper and lower beds, termed as A and B shale beds, based on the HIo value. Generally, the stratigraphic correlation between boreholes is based on well-log data; the data have information about lithology and other characteristics for beds. Stratigraphic interpretation in boreholes is based on reference data such as well-header information, mud logging 


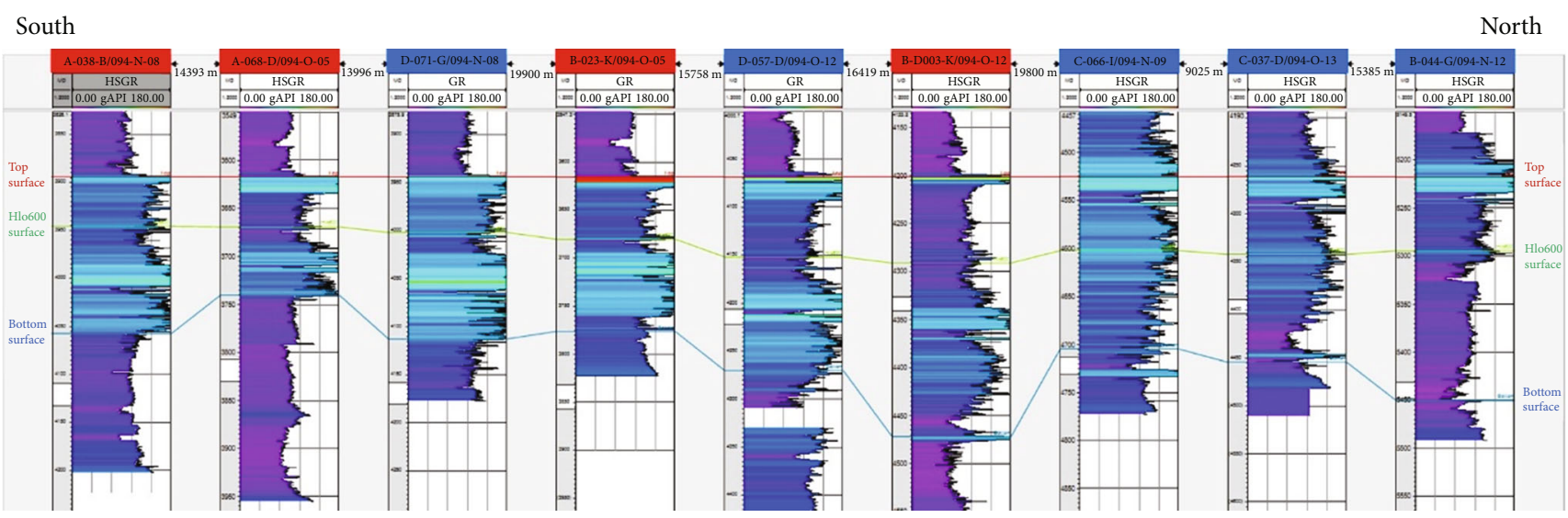

FIGURE 4: Correlation of three surfaces among the boreholes based on GR and HIo. This figure only shows gamma-ray logs in boreholes.

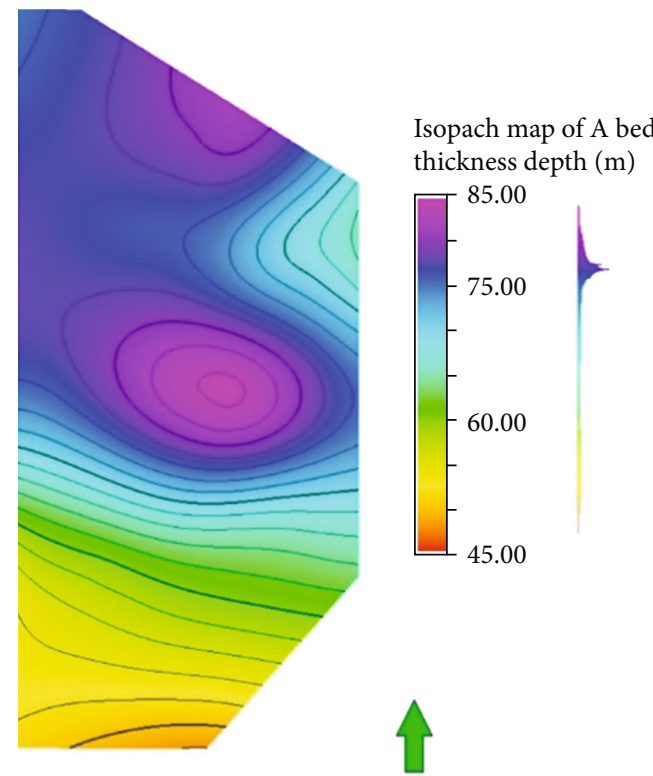

(a)

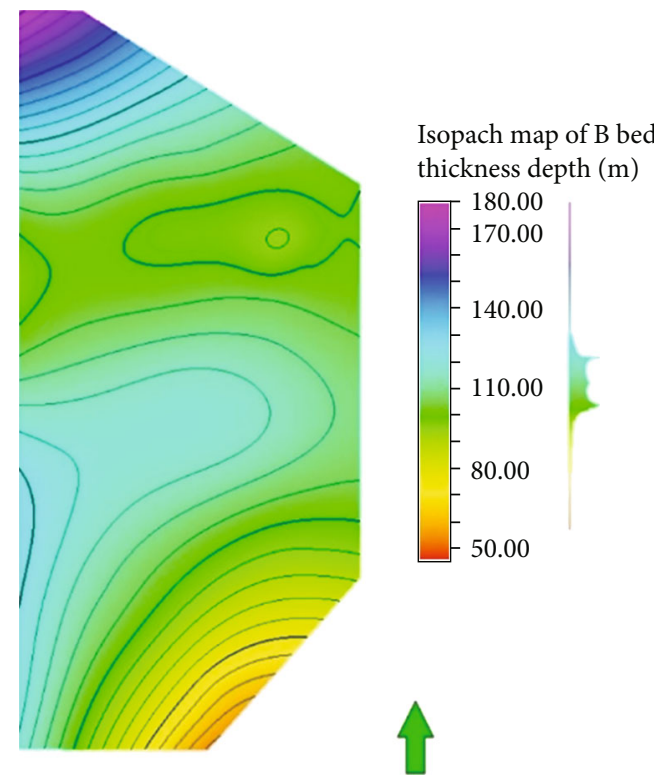

(b)

Figure 5: Isopach maps of the A shale bed (a) and the B shale bed (b). Thickness tends to increase toward the north, and relatively, the B bed is thicker than the A bed.

data, and research articles on the same study area. Furthermore, in accordance with subject of the research or project, referred data can be switched or changed with the others. In this study, the top of the prospective shale bed was correlated with the well-log and information. In addition, abrupt vertical variation of HIo in the boreholes was considered for maturity in each bed, because $\mathrm{HI}$ is a value to expect thermal maturity in source rock. The A shale bed (upper) shows a number less than $600 \mathrm{mgHI} / \mathrm{TOCg}$ and B shale bed (lower) shows a number over than $600 \mathrm{mgHI} / \mathrm{TOCg}$ [16] (Figures 3 and 4). The B shale bed is thicker than the A shale bed and tends to get thicker from south to north gradually (Figure 5). Among the nine boreholes having well-log data, only four have geochemical data (Figures 1 and 4).

3.2. Original TOC (TOCo) Calculation. The initial generative capacity within the source rocks can be expected in terms of
TOCo and estimated to determine the generation potential of the source rocks [10]. The TOCo, which is the initial total organic carbon, is calculated by the empirical Equation (2) [9, 22]. In Equation (2), present-day generative organic carbon (GOCpd) is organic carbon existing in the rock, and it can be possibly transformed to hydrocarbon (HC). In contrast, present-day nongenerative organic carbon (NGOCpd) is organic carbon which does not have any potential to transform the HC; Equation (2) $[9,22]$ is as follows:

$$
\text { TOCo }=\frac{\text { NGOCpd }- \text { GOCpd }}{(1-\text { HIo/1177) } \times 100} .
$$

The properties of Equation (2) can be calculated or obtained by the results of the Rock-Eval pyrolysis; however, the data is only available for the four boreholes. Hence, in 

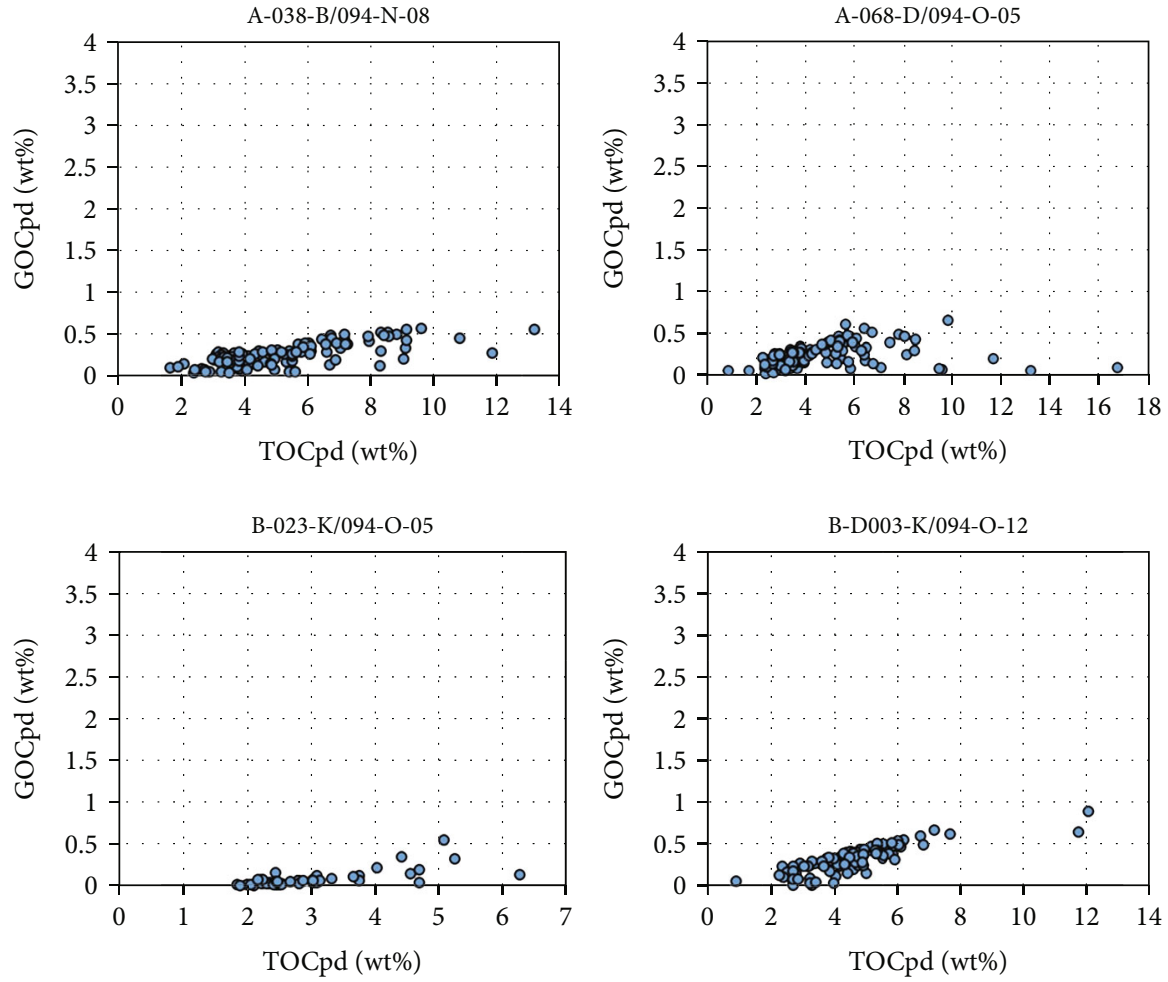

FIGURE 6: Correlation between calculated GOCpd and measured TOCpd of A-038-B/094-N-08 [17] and A-068-D/094-O-05 [18], and B-023K/094-O-05 [19] and B-D003-K/094-O-12 [19] GOCpd shows a relatively very small weight percent (wt\%) compared to TOCpd and is less than $1 \mathrm{wt} \%$ in four boreholes.
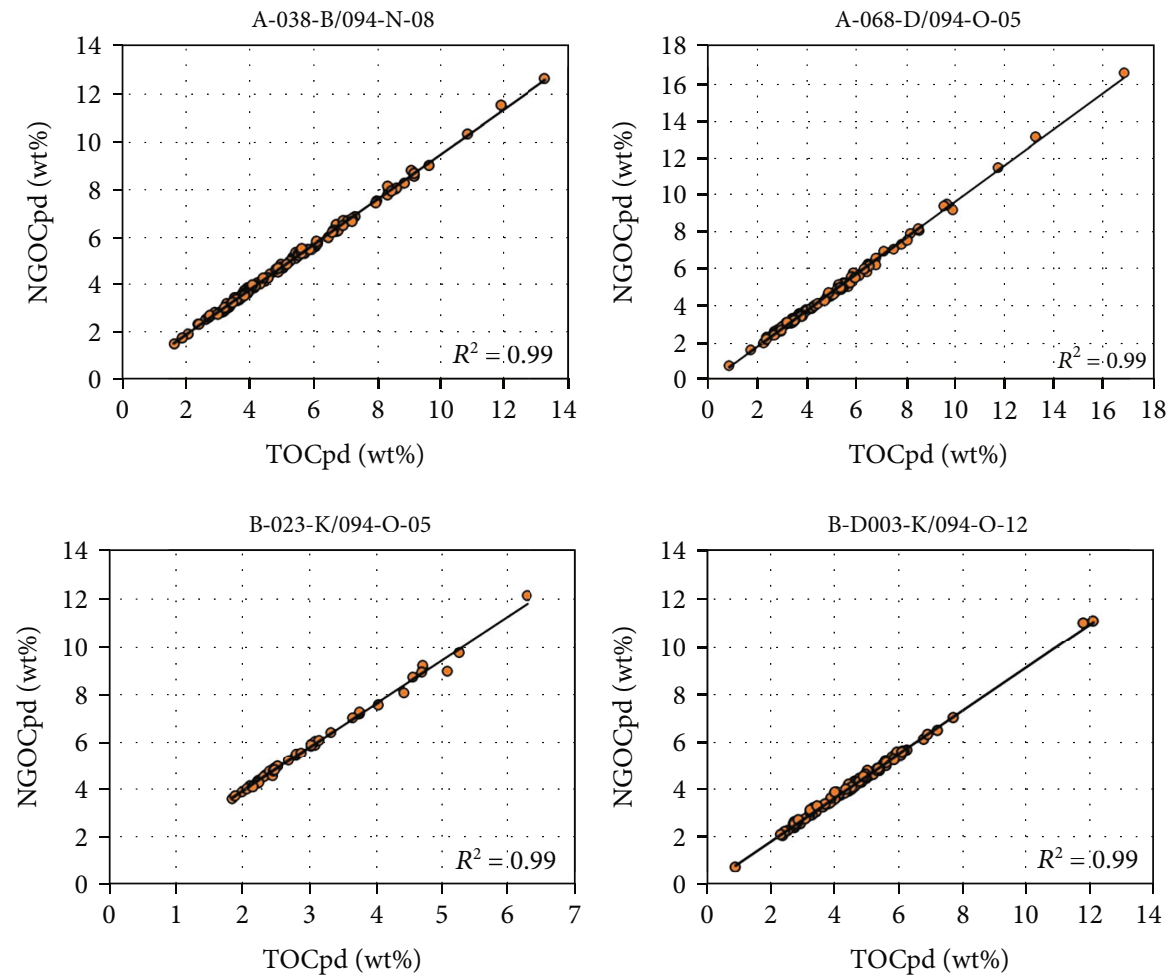

FIGURE 7: Correlation between calculated NGOCpd and TOCpd of A-038-B/094-N-08 [17] and A-068-D/094-O-05 [18], and B-023-K/094O-05 [19] and B-D003-K/094-O-12 [19]. These boreholes have considerably high coefficient of determinations. The NGOCpd can be alternative to TOCpd in Equation (2). 

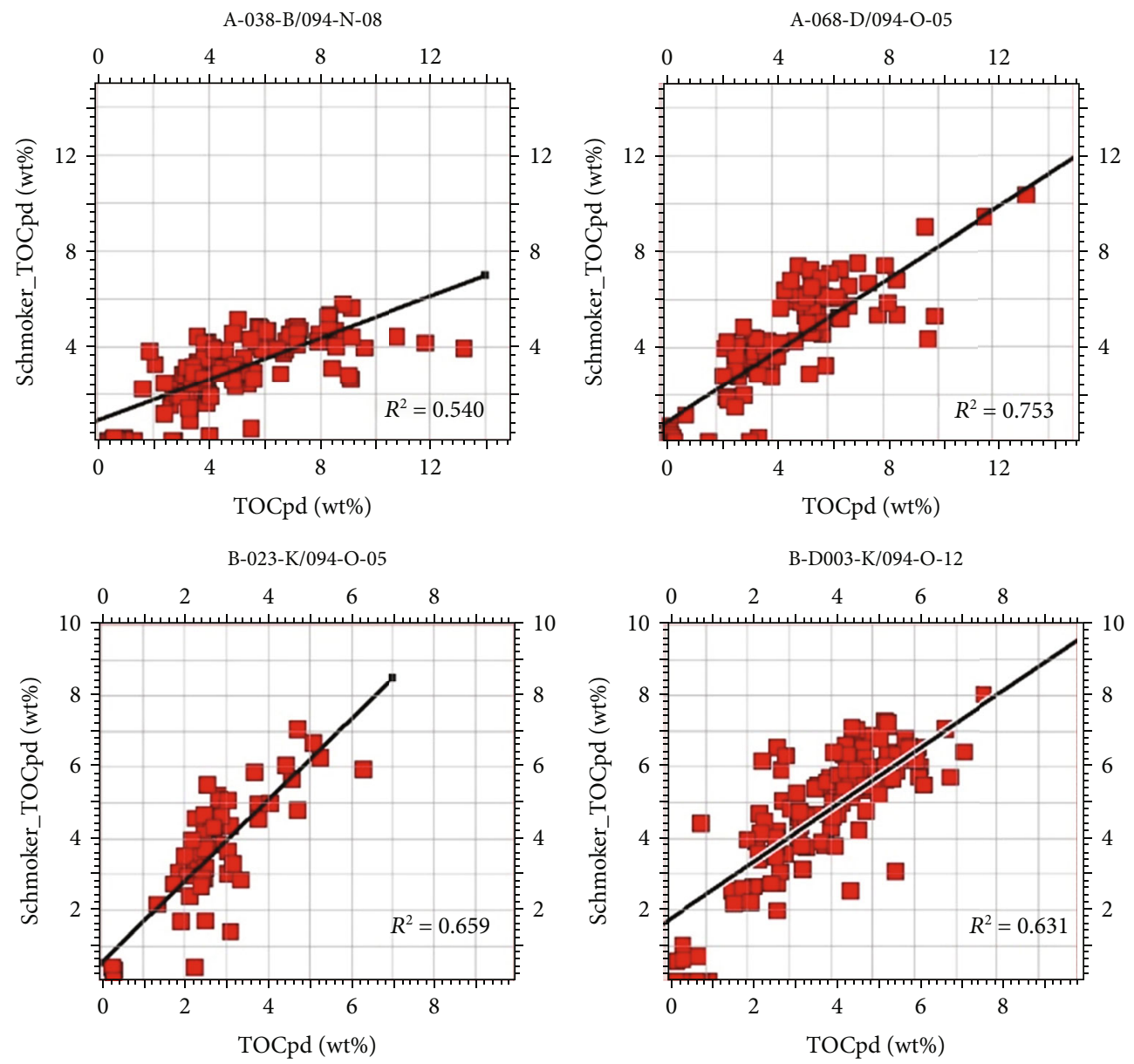

FIGURE 8: Correlation between calculated TOCpd (Schmoker_TOCpd) and measured TOCpd of A-038-B/094-N-08 [17] and A-068-D/094O-05 [18], and B-023-K/094-O-05 [19] and B-D003-K/094-O-12 [19]. Coefficients of determinations are from 0.540 to 0.753; these value means that the Schmoker_TOCpd has a substitute instead of measured TOCpd in boreholes without geochemical data.

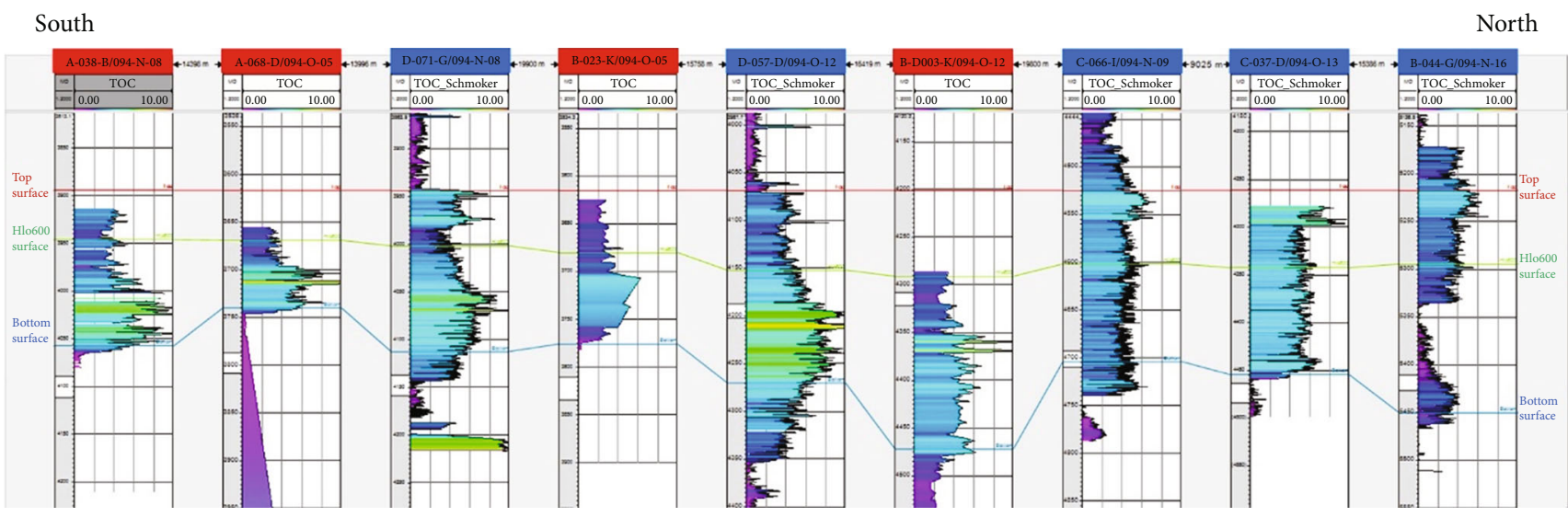

Figure 9: Measured TOCpd (TOC, red color) [17-19] and calculated TOCpd (TOC_Schmoker, blue color) using Schmoker's equation.

order to calculate TOCo for the boreholes lacking geochemical data, Equation (2) must be modified. For this reason, the HIo was applied as the average value in the $\mathrm{A}$ and $\mathrm{B}$ shale beds. Average values for HIo are $447 \mathrm{mgHC} / \mathrm{gTOC}$ in the A bed and $670 \mathrm{mgHC} / \mathrm{gTOC}$ in the B bed.
TOC consists of present-day generative organic carbon (GOCpd) and present-day nongenerative organic carbon (NGOCpd). The GOCpd is the organic carbon remaining in the present day and has the capacity to transform into hydrocarbons. On the other hand, the NGOCpd rarely 


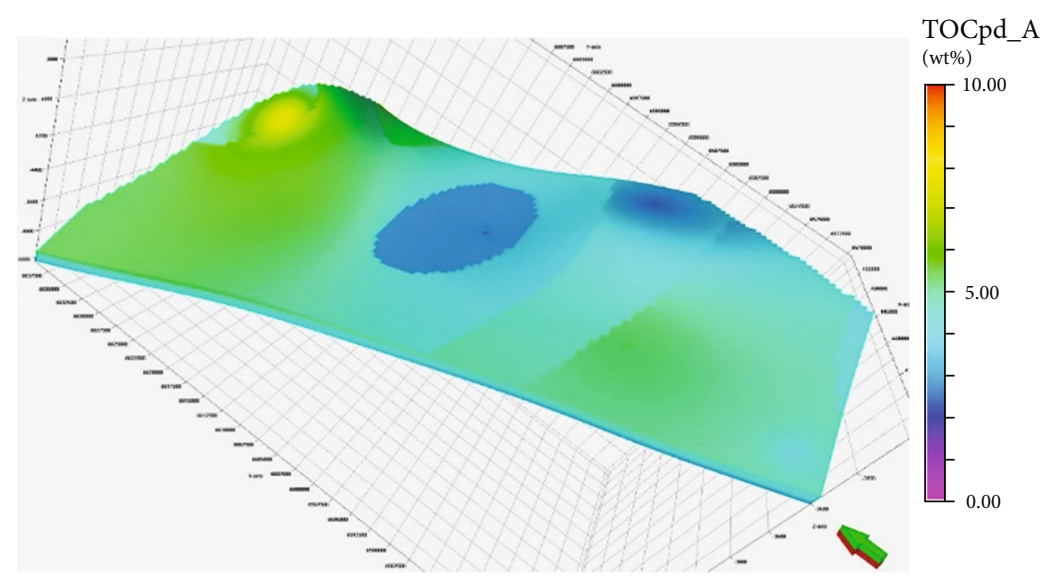

(a)

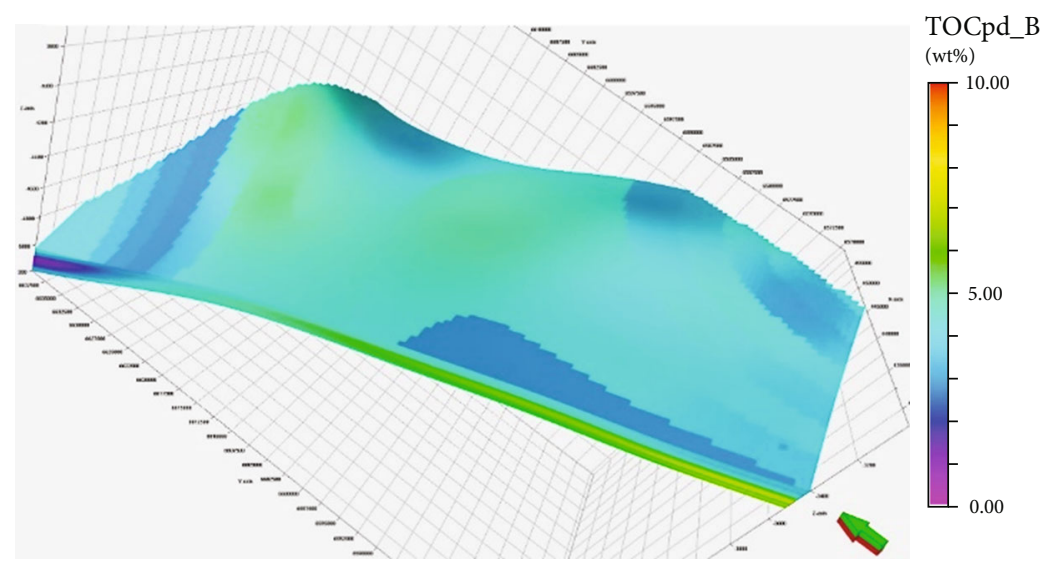

(b)

FIGURE 10: 3D distribution of TOCpd of the A shale bed (a) and the B shale bed (b) in the study area ( $\times 20$ vertical exaggeration). In the A and $B$ beds, the TOCpd between 3 and 6 weight percent is dominant in the study area.

transforms into hydrocarbons [19]. The GOCpd and NGOCpd were estimated by using the data of Hong et al., Kim et al., and Choi et al. [17-19]. Matured to overmatured source rock in the A and B beds [12] includes little GOCpd (Figure 6); the value is too low to affect the estimation of TOCo. Hence, GOCpd was not considered in Equation (2).

The relationship between NGOCpd and TOCpd shows a high coefficient of determination over 0.9 (Figure 7). Therefore, NGOCpd substituted the TOCpd value, in Equation (3).

$$
\text { TOCo }=\frac{\text { TOCpd }}{(1-\text { HIo/1177) } \times 100} .
$$

3.3. Calculation of TOCpd from Well-Log Data. Generally, TOCpd is measured from the source rock by geochemical analysis such as the Rock-Eval pyrolysis method. Many researches have been conducting estimation of TOCpd using only well-log data without further geochemical analysis $[21,23,24]$.

The Besa River Formation mainly consists of shale with little pyrite, which is considered as a heavy mineral in shale [11-14]. Schmoker's experimental equation can account for pyrite $[20,21]$; hence, the equation was used to consider the influence of the mineral in the Besa River Formation.

Schmoker's TOCpd was calculated using the bulkdensity log of the boreholes having TOCpd via geochemical analysis and then validated against the measured TOCpd of the boreholes. The relationship between measured TOCpd and Schmoker's TOCpd shows a high coefficient of determination in the range $0.540-0.753$ (Figure 8). Thus, Schmoker's TOCpd was applied to calculate the TOCo. The measured and calculated TOCpd of boreholes are shown in Figure 9.

3.4. 3-Dimensional Geochemical Static Modeling. The 3D distribution of TOCpd was realized in the structure grid model using the moving average method (Figure 10). The moving average method is one of the interpolation methods; this uses an average, which is weighted by inverse of the distance, of surrounding samples to the specific point. The number of boreholes in this study is limited to analysis spatial distribution such as variogram modeling; for this reason, the method is used to realize $3 \mathrm{D}$ property modeling. The TOCo model was generated based on the TOCpd model, using Equation (3), where in the average HIo value used 


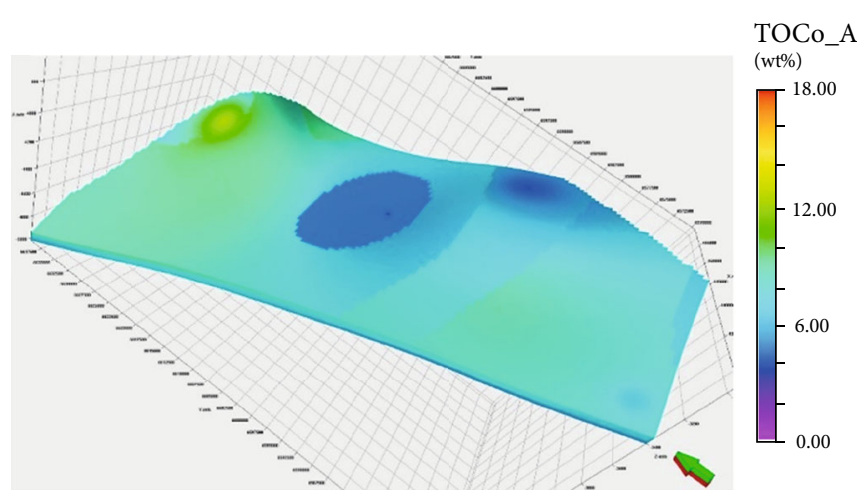

(a)

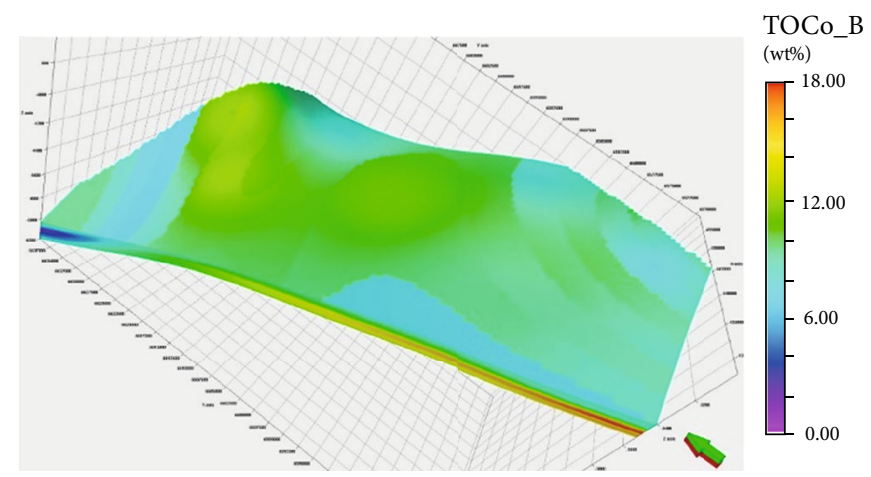

(b)

Figure 11: 3D distribution of TOCo of the A shale bed (a) and the B shale bed (b) in the study area ( $\times 20$ vertical exaggeration). Relatively high TOCo distribution in the A bed is shown at the upper layer and northwestern region and in the B bed is shown at the lower layer and southern region.

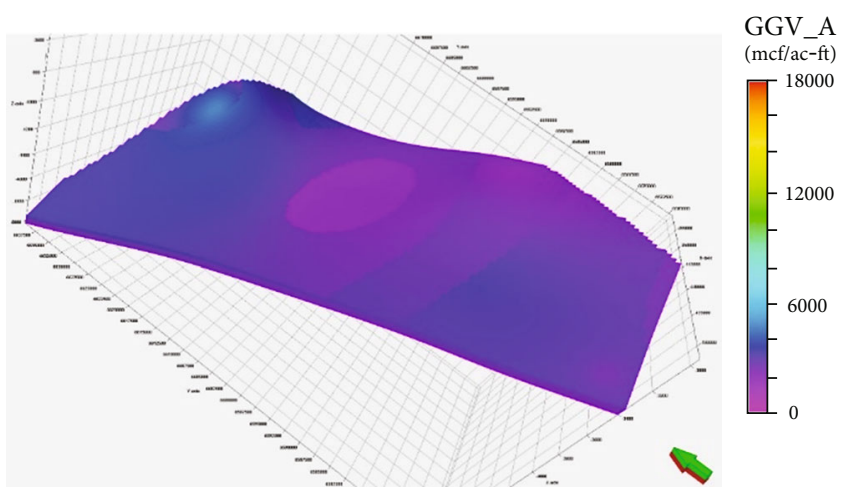

(a)

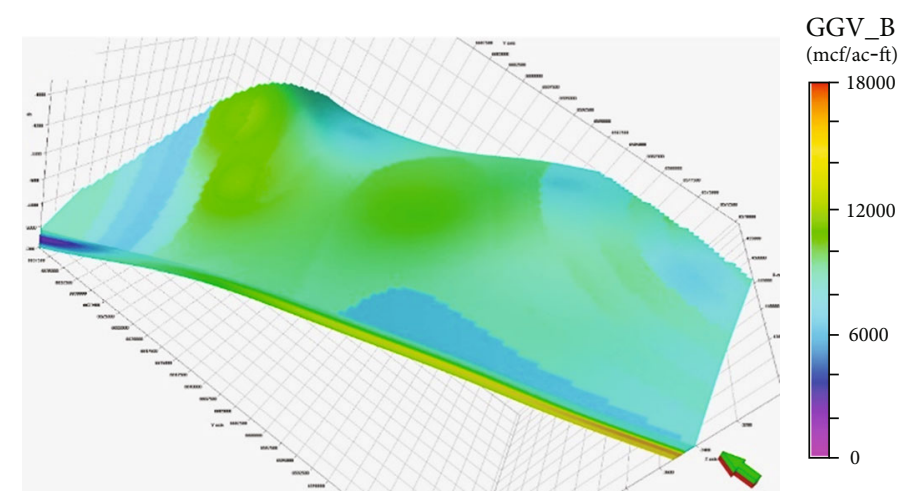

(b)

Figure 12: 3D distribution of generated gas volume (GGV) in the A shale bed (a) and the B shale bed (b) in the study area ( $\times 20$ vertical exaggeration). Estimated generated gas volume in the A shale bed and B shale bed shows a range from approximately 2,000 to 3,000 and a range from 8,000 to $14,000 \mathrm{mcf} / \mathrm{ac}-\mathrm{ft}$ (million cubic feet per acre-ft).

was $447 \mathrm{mgHI} / \mathrm{gTOC}$ for the A shale bed and $670 \mathrm{mgHI} / \mathrm{g}$ TOC for the B shale bed (Figure 11).

Models for 3D geochemical properties-TOCpd (Figure 10) and TOCo (Figure 11)-were generated for prospective shale beds in the Liard Basin. From TOCo volume and Equation (4) [10], the original generation potential $\left(S_{20}\right)$ of the shale gas beds could be estimated. The potential value indicated the hydrocarbon content in the rocks; thus, the potential was converted to the generated gas volume (Figure 12).

$$
\mathrm{S}_{2 o}=\left[\frac{\text { TOCo } \times(\mathrm{HIo} / 1177)}{0.085}\right] .
$$

\section{Results and Discussion}

This study shows the realized 3D distribution of estimated gas volume using geochemical data and well-log data in the Liard Basin. The GGV in the B shale bed is higher than that in the A shale bed (Figure 12). Figure 12 shows that generated gas volume without considering for expulsion of gas volume. This indicates that the $\mathrm{B}$ bed has higher generative potential than the A bed. Expulsion efficiencies have to consider estimating accurate gas volume in the shale gas reservoir in the subsurface. Hence, several studies have researched predicting the expulsion efficiency [25-30]. Therefore, in this study, the expulsion efficiency is considered to accurately estimate the retained gas volume which is considered as the GIP in the static model; the efficiency was assumed as 0.6 [10].

The retained gas volume is compared with GIP of the production well (200/C-045-K/094-O-05/2), which is located in the study area (Figure 1). The GIP about the well is $496 \mathrm{Bcf}$ (billion cubic feet)/section, and the retained gas volume is $262 \mathrm{Bcf} /$ section in the well location on the model. Although the order of the GIP value of the well and the model is similar, the value in the model is much lower than that of the well. This indicates that the GIP model estimated from the geochemical static model could suggest the approximate prospective area where there is an undeveloped place in the 
basin. The gap between GIP values may be caused by the difference in volume of the estimated model and the affected volume due to hydraulic fracturing on the subsurface. It is difficult to predict the reservoir scale of induced cracks around a wellbore due to fracturing without microseismic data.

Furthermore, the model represents the GIP in the study area; hence, it cannot explain petroleum generation, migration, and accumulation in the shale bed because the static model does not mimic changes from basin evolution. On the other hand, petroleum system modeling is another method to estimate generated and retained gas volumes in the source rock; moreover, it can suggest generation and migration time and place $[29,31,32]$. Hence, in order to understand the geological processes, data and information such as temperature, pressure, burial history, thermal maturity, and stratigraphy are required, followed by additional research for petroleum systems and processes.

The initial state of the properties is emphasized by researches $[9,10,30,33]$; however, these original properties can be calculated indirectly via data by laboratory experiments. This geochemical static model was based on these original geochemical properties, though assumptions and constant values in the overall estimation process should be revised for the entire Liard Basin.

\section{Conclusion}

This study determines the spatial prospective area via shale gas reservoir characterization for the prospective shale beds of the Besa River Formation in Liard Basin. The stratigraphic correlation among the wells realizes the stratigraphy and structural interpretation results for beds using HIo and gamma rays of the wells. Spatial TOCo distribution is realized by TOCpd and a structure grid model by the correlation result. Furthermore, correlation of determination between measured TOCpd by the Rock-Eval analysis and calculated TOCpd by bulk density log shows from 0.540 to 0.753 . So the bulk density log of the boreholes without rock samples provides information regarding the estimated TOCpd value. From the measured HIo and estimated TOCo, generated and retained gas volume (262 Bcf/section) is calculated; this static model may aid in Basin exploration and development plans and function as a preliminary or reference model for the Basin.

\section{Data Availability}

The raw data of the geochemical analysis performed in this study are available from the corresponding author upon request.

\section{Conflicts of Interest}

The authors declare that there are no conflicts of interest regarding the publication of this paper.

\section{Acknowledgments}

This work was supported by the Korea Institute of Energy Technology Evaluation and Planning (KETEP); the Ministry of Trade, Industry \& Energy, Republic of Korea (MOTIE) (No. 20178510030880); and the Korea Institute of Geoscience and Mineral Resources (KIGAM) (No. GP2020-006). The authors are thankful to the British Columbia Oil and Gas Commission (BCOGC) for providing valuable field data and the great help for publishing this research article. In particular, the authors are grateful to Mr. Filippo Ferri and Dr. Hamed Senai for their helpful comments on this article.

\section{References}

[1] British Columbia's Oil and Gas Reserves and Production Report, BC Oil and Gas Commission, 2018.

[2] National Energy Board, The Unconventional Gas Resources of Mississippian-Devonian Shales in the Liard Basin of British Columbia, the Northwest Territories and Yukon, 2018, https://www.cer-rec.gc.ca/nrg/sttstc/ntrlgs/rprt/ ltmtptntlbcnwtkn2016/ltmtptntlbcnwtkn2016-eng.pdf.

[3] Z. Chen, C. Jiang, D. Lavoie, and J. Reyes, "Model-assisted Rock-Eval data interpretation for source rock evaluation: examples from producing and potential shale gas resource plays," International Journal of Coal Geology, vol. 165, pp. 290-302, 2016.

[4] C. Geel, H. M. Schulz, P. Booth, M. de Wit, and B. Horsfield, "Shale gas characteristics of Permian black shales in South Africa: results from recent drilling in the Ecca group (Eastern Cape)," Energy Procedia, vol. 40, pp. 256-265, 2013.

[5] D. W. Morrow, J. Potter, B. Richards, and F. Goodarzi, "Paleozoic burial and organic maturation in the Liard Basin region, northern Canada," Bulletin of Canadian Petroleum Geology, vol. 41, no. 1, pp. 17-31, 1993.

[6] F. Wang and S. Guo, "Shale gas content evolution in the Ordos Basin," International Journal of Coal Geology, vol. 211, article 103231, 2019.

[7] M. M. Al-Hajeri, M. Al Saeed, J. Derks et al., "Basin and petroleum system modeling," Oilfield Review, vol. 21, no. 2, pp. 1429, 2009.

[8] K. E. Peters, O. Schenk, A. H. Scheirer, B. Wygrala, and T. Hantschel, "Basin and petroleum system modeling," Springer Handbook of Petroleum Technology, pp. 381-417, 2017.

[9] S. K. Hong, Y. J. Shinn, J. Choi, and H. S. Lee, "Estimation of original kerogen type and hydrogen index using inorganic geochemical proxies: implications for assessing shale gas potential in the Devonian Horn River Formation of western Canada," AAPG Bulletin, vol. 102, no. 10, pp. 2017-2099, 2018.

[10] D. M. Jarvie, R. J. Hill, T. E. Ruble, and R. M. Pollastro, "Unconventional shale-gas systems: the Mississippian Barnett Shale of North-Central Texas as one model for thermogenic shale-gas assessment," AAPG Bulletin, vol. 91, no. 4, pp. 475-499, 2007.

[11] E. E. Pelzer, "Mineralogy, geochemistry and stratigraphy of the Besa River shale, British Columbia," Bulletin of Canadian Petroleum Geology, vol. 14, no. 2, pp. 273-321, 1966.

[12] F. Ferri, A. S. Hickin, and D. H. Huntley, "Besa River Formation, western Liard Basin, British Columbia (NTS 094N): 
geochemistry and regional correlations," Geoscience Reports, vol. 2011, pp. 1-18, 2011.

[13] F. Ferri, A. S. Hickin, and J. Reyes, "Horn river basin-equivalent strata in Besa River Formation shale, northeastern British Columbia (NTS 094K/15)," Geoscience reports, vol. 2012, pp. 1-15, 2012.

[14] F. A. Kidd, “The Besa River Formation," Bulletin of Canadian Petroleum Geology, vol. 11, pp. 369-372, 1963.

[15] D. J. Ross and R. M. Bustin, "Investigating the use of sedimentary geochemical proxies for paleoenvironment interpretation of thermally mature organic-rich strata: examples from the Devonian-Mississippian shales, Western Canadian Sedimentary Basin," Chemical Geology, vol. 260, no. 1-2, pp. 1-19, 2009.

[16] F. Ferri, M. McMechan, and R. Creaser, "The Besa River Formation in Liard Basin, British Columbia," Oil and Gas Geoscience, vol. 2015, pp. 1-27, 2015.

[17] S. K. Hong, K. Lee, H. S. Lee et al., "Assessment of shale gas potential from geochemical data in the late Devonian shale succession, Liard Basin, Canada," Journal of Petroleum Science and Engineering.

[18] Y. Kim, J. Choi, K. H. Kim et al., "Brittleness and hardness of the Besa River Formation in Liard Basin, Canada," Geofluids.

[19] J. Choi, H. S. Lee, Y. Kim et al., "Multiple controls on the accumulation of organic-rich sediments in the Besa River Formation of Liard Basin, Canada," Geofluids.

[20] J. W. Schmoker, "Determination of organic content of Appalachian Devonian shales from formation-density logs: geologic notes," AAPG Bulletin, vol. 63, no. 9, pp. 1504-1509, 1979.

[21] J. W. Schmoker and T. C. Hester, "Organic carbon in Bakken formation, United States portion of Williston basin," AAPG Bulletin, vol. 67, no. 12, pp. 2165-2174, 1983.

[22] D. M. Javie, "Shale resource systems for oil and gas: part I-shale gas resource systems. Part II-shale oil resource systems. Shale reservoirs-giant resources for the 21st century," AAPG Memoir, vol. 97, pp. 69-87, 2012.

[23] Q. R. Passey, S. Creaney, J. B. Kulla, F. J. Moretti, and J. D. Stroud, "A practical model for organic richness from porosity and resistivity logs," AAPG Bulletin, vol. 74, no. 12, pp. 17771794, 1990.

[24] B. Lecompte and G. Hursan, "Quantifying source rock maturity from logs: how to get more than TOC from delta log R," Society of Petroleum Engineers, 2010.

[25] A. K. Burnham and R. L. Braun, "Development of a detailed model of petroleum formation, destruction, and expulsion from lacustrine and marine source rocks," Organic Geochemistry, vol. 16, no. 1-3, pp. 27-39, 1990.

[26] Z. Chen and C. Jiang, "A revised method for organic porosity estimation in shale reservoirs using rock-Eval data: example from Duvernay Formation in the Western Canada Sedimentary Basin," AAPG Bulletin, vol. 100, no. 3, pp. 405-422, 2016.

[27] K. Nakayama, "Hydrocarbon-expulsion model and its application to Niigata area, Japan," AAPG Bulletin, vol. 71, no. 7, pp. 810-821, 1987.

[28] I. Ozkaya and A. Akbar, "An interative procedure to determine depth and time of primary oil migration and expulsion efficiency of source rocks," Journal of Petroleum Science and Engineering, vol. 5, no. 4, pp. 371-378, 1991.

[29] M. R. Shalaby, M. H. Hakimi, and W. H. Abdullah, "Geochemical characteristics and hydrocarbon generation modeling of the Jurassic source rocks in the Shoushan Basin, North West- ern Desert, Egypt," Marine and Petroleum Geology, vol. 28, no. 9, pp. 1611-1624, 2011.

[30] E. Wang, G. Liu, X. Pang et al., “An improved hydrocarbon generation potential method for quantifying hydrocarbon generation and expulsion characteristics with application example of Paleogene Shahejie Formation, Nanpu Sag, Bohai Bay Basin," Marine and Petroleum Geology, vol. 112, article 104106, 2020.

[31] P. Wang, Z. Chen, Z. Jin et al., "Shale oil and gas resources in organic pores of the Devonian Duvernay shale, Western Canada Sedimentary Basin based on petroleum system modeling," Journal of Natural Gas Science and Engineering, vol. 50, pp. 33-42, 2018.

[32] J. Zhang, J. Guo, J. Liu, W. Shen, N. Li, and G. Xu, “3D-basin modelling of the Lishui Sag: research of hydrocarbon potential, petroleum generation and migration," Energies, vol. 12, no. 4, article 650, 2019.

[33] Z. Chen and C. Jiang, "A data driven model for studying kerogen kinetics with application examples from Canadian sedimentary basins," Marine and Petroleum Geology, vol. 67, pp. 795-803, 2015. 